\title{
THE COLLECTIVE ACTIONS HELD HOSTAGE BY
}

\section{THE AUTHORITARISM}

Ada Pellegrini Grinover

Full Professor at the Law College at University of São Paulo.

\begin{abstract}
The judicial protection of collective interests represents, at the end of the millennium, one of the most impressive conquests of the Brazilian legal system. The transindividual interests which are particular to mass society are full of political relevance and, to that extent, are capable of transforming stratified judicial concepts. The recognition of these interests and the need to protect them have highlighted their political configuration in Brazil. In this way, the theory of public liberty forged a new "generation" of fundamental rights. In the same way, one can note that, at the constitutional level, the concepts of jurisdiction and litigation were renewed, while some fundamental guarantees were reformed. The most notable revolution, however, might have taken place in the procedural sphere, departing from an individual process model toward a social process model In Brazil, the Judiciary power has also taken advantage of class action lawsuits in terms of rationalization and work projection. The social objective of the judicial function was lost in view of the fragmentation and the pulverization of conflicts, always regarded as individual. There is a notable tendency to replace atomized decisions with a molecular treatment of litigation. Nevertheless, the Executive power has revealed itself to be inattentive to the reality of collective action and has tried to reduce its effectiveness, limiting access to courts, compressing the associative moment, and diminishing the role of the Judiciary. In this perspective, many years after the introduction of judicial protection for collective and diffuse interests in Brazil, the balance would have been positive, had the government not adopted an authoritarian line when applying legal treatment to the matter. It is possible to affirm that collective actions are a part of the current legal routine, despite the attacks which they suffer. The Judiciary power is significantly implanted in this context, it is conscious of its new role and of its renewed importance, and by way of its sentences, it was capable of occupying a position of leadership which points toward future challenges. The only note that rings false in this context is the attitude of the government with relation to the use of Provisional Measures to reverse such a situation, attacking collective actions and trying to diminish their efficiency in order to limit the access to Justice, to frustrate the associative moment and to make the Judiciary seem less important. The Legislative power, complacent or
\end{abstract}


inattentive, has not been able to resist the attacks and to react to the attitudes of the government.

Keywords: Collective actions - Applicability - Panorama - Brazilian law.

\section{THE SOCIAL, POLITICAL AND LEGAL SCOPE OF THE JURISDICTIONAL PROTECTION FOR THE TRANSINDIVIDUAL INTERESTS}

The jurisdictional protection for the diffuse, collective and homogeneous individual interests represents, at the end of the millennium, one of the most impressive achievements of the Brazilian legal system. The transindividual interests, which are placed halfway between the public and the private interests, are peculiar to the mass society, have resulted from mass conflicts, are full of political relevance, and are capable of transforming stratified legal concepts..

From a social standpoint, they represented the acceptance and the necessity to protect scattered and informal interests, which are turned to collective needs, being, in a sense, related to the quality of life. They are mass interests that admit mass offences and that contrast groups of people, social categories and classes. Among the holders of those interests are the consumers, the environment, the public service users, the investors, the social welfare beneficiaries and all those who are part of a community and share their needs and expectations.

The recognition of those interests and the necessity to protect them highlighted their political configuration. New ways of managing public issues have emerged, and enabled the intermediate groups to strengthen their position. A participative management, as a tool to rationalize the power, inaugurated a new type of decentralization, no longer limited to the state level (as political and administrative decentralization), but extended to the social level, with tasks assigned to the intermediate bodies and to the social formations, which have autonomy and specific functions. It also meant a reorganization of the society towards associations and groups.

Consequently, the theory of the public liberty has forged a new "generation" of fundamental rights. The acceptance of third-generation rights, represented by the solidarity rights arising from social interests, was added to the classical first-generation rights, which consist of the traditional negative liberties prominent in liberal states, and include the corresponding abstention requirement by the government. It was also added to the second-generation rights, of economic and social nature, which include the positive liberties, as well as the corresponding duty of 
the state to "dare", "facere" or "praestare". Then, what at first seemed a mere interest turned out to be a true right, which led to the restructuring of the legal concepts so that they could fit the new reality.

At the constitutional level, the meanings of jurisdiction and action were renewed, while fundamental guarantees, such as the adversarial system, were remodeled. It was necessary to revise the classical concept of civil liability, calculated, until that time, on the basis of the harm suffered and, therefore, the concept of civil liability for damages was introduced. Concerning the legal process, some consolidated concepts were revisited, such as the standing, the res judicata, the partially identical demands and the judge's power and the Attorney General's responsibility.

The most outstanding revolution, however, may have happened at the procedural level: from an individualist procedural model to a social model, from abstract to concrete schemes, from static to dynamic ground, the procedural law changed from individual to collective, sometimes getting its inspiration from the class actions in the common law, sometimes creating new techniques, more adherent to the social reality and to the underlying policy.

All the above changed the context of the access to justice, which was simplified by those who have the standing to bring the transindividual interests to court, and who, in turn, replaced the individual litigants, considered economically and organizationally weak, and who simply did not use to bring their claims to court. This way, a new reality to the principle of universal jurisdiction was designed, and thus, became open to new causes and new litigants.

\section{A NEW JUDICIAL SYSTEM}

In Brazil, the judicial power has also taken advantage of the collective actions in terms of work projection and rationalization. The Court of Appeals' overload and the feeling that the individual decisions were useless were aggravated by the contradictory decisions and the delay of having the lawsuits judged. The social purpose of the jurisdictional function, which is to pacify conflicts and to be fair at the same time, was lost in view of the fragmentation and the pulverization of the conflicts, always looked at as being individual. The substitution of the atomized decisions (as defined by Kazuo Watanabe) for the molecular treatment of the litigations, taking to court all at once conflicts that involve thousands or millions of people, meant to make the judge the main character to lead the mass actions, which are often considered politically and socially relevant due to the fact that they include mass conflicts. Thanks to the collective actions the judicial power abandoned its frequently distant and remote position in order to play the main role 
in the big national controversies.

\section{THE EXECUTIVE BRANCH ON THE WRONG SIDE OF HISTORY}

Despite all the above, the assaults from the executive branch together with a complacent and, at the very least, inattentive legislative power have attacked the collective actions, trying to reduce its effectiveness by limiting the access to the courts, by compressing the associative moment, and by decreasing the role of the judiciary.

Some clear manifestations of those attacks are the Provisional Measure n. 1.570 of March 26, 1997 (enacted as Law number 9.424 of September 10, 1997) and the Provisional Measure number 1.798-1 of February 11, 1999;

At least in part, the government intentions were plainly frustrated. The application of the new rules will depend on the reading of the Constitution. And, once again, the judiciary branch will be in charge of developing an interpretation that may take into account the unity of the legal system as well as the exegesis which may be more consistent with the general principles of law.

Our analysis will focus, then, on those authoritarian interventions of the government.

\section{THE RES JUDICATA AND ITS NATIONAL EFFECTS}

Prior to the Provisional Measure number 1.570 of March 26, 1997, which was enacted as Law number 9.494 of September 10, 1997 (it will be dealt with again in number 5), the national effects of the res judicata erga omnes had some drawbacks in the Court of Appeals, which applied jurisdiction criteria to limit the effects of both the preliminary injunction and of the judgment.

Therefore, we assert that it does not make any sense, for instance, to file in the capital city of each state the lawsuits intended to protect the homogeneous individual interests of the Social Security pensioners and retired to award them the $147 \%$ difference they were entitled, under the pretext of the territorial limits concerning the several branches of the federal court system. It is not a problem of jurisdiction: the judge, competent to process and decide the litigation, shall make a decision (preliminary or definite), which is effective erga omnes and shall be extensive to all the retired people and pensioners in Brasil. Either the action is a collective one or it is not. Either the res judicata is erga omnes or it is not. And if the claim is really a collective one there will be a clear relation of pendency among the several lawsuits filed in the various federated states. 
That is the reason why we are for the idea that the limitations arising from certain decisions confront the Article 103 of the Consumer Protection Code and despise the orientation provided by the Article 91, II, in which one can read that the action for damages with a national or regional scope shall be filed in the capital city of the state or in the Federal District, but the decision will, of course, be applicable all over the national territory. This rule applies to all the other cases of interests that may refer to groups and categories of people, which are more or less determinable, and located all over the national territory.

Hence, in the case of Conflict of Jurisdiction number 971-DF, judged by the First Section of the Supreme Court (STJ) on February 13, 1990, the reporting Justice Ilmar Galvão properly recognized in his vote the prevention of the 30th Federal Court in Rio de Janeiro from acknowledging and deciding on the collective action that prohibited to blend methanol with alcohol and, then, distribute and sell it as fuel to consumers all over the national territory. The reporting Justice stated:

"I carefully considered the possibility of admitting that a decision arising from a monocratic legal system, with the same nature sought in the analyzed actions, may be effective beyond the boundaries of the territory where its jurisdiction is exercised, and I could not find any rule capable of leading to a negative conclusion.

The regionalization of the federal courts does not seem to me to be an obstacle to that already mentioned effect and, likewise, it is certain that, for the justice at the state-level, a judge with jurisdiction in a certain state is not prevented from issuing a specific decision that can project its effects over the people who reside in other states.

The present case becomes greater because it is about actions to protect the diffuse interests. Therefore, it is not reasonable to expect v.g. that the occasional prohibition of toxic emanations shall be forcefully restricted to just one region, considering that everyone is free to stay there or to come and go even though they reside somewhere else."

The reporting Justice's vote was followed by those from Justices José de Jesus and Geraldo Sobral; however, Justice Vicente Cernicchiaro's position has prevailed. He understood that the suits 
should be processed apart, and the respective decisions should be effective in each court's jurisdiction.

That decision, prior to the Consumer Protection Code, has determined the opinion of many other Courts of Appeals that had once limited the extension of the res judicata erga omnes or ultra partes, due to the rules governing the courts' jurisdiction.

That attitude had influence on some pleadings, which became restricted to the territory covered by the regionalization rules of the Brazilian Courts of Appeals, in accordance with the referred orientation.

In other cases, however, the plaintiffs continued to plead correctly in more comprehensive terms. They claimed and obtained preliminary injunctions, effective all over the national territory. In many lawsuits the first instance condemnatory decisions did not make any territorial restrictions towards the extent of the res judicata erga omnes.

Little by little, the jurisprudence became solid towards the idea that the res judicata ultra partes or erga omnes could go further than the territorial jurisdiction in order to assume a regional or national dimension.

Just as mere examples, it is worth remembering some decisions made in national terms.

The Regional Federal Court for the Third Region sustained the preliminary injunction of the 17th Court in São Paulo concerning the suspension of bank fees, authorized by the Central Bank, imposed on savings accounts, which were inactive or without registration renewal, effective all over the national territory (Bill of Review nr. 96.03.0646776, Third Group, reporting Annamaria Pimentel, v.u. October 30, 1996. The report pointed out that the effects of a decision or judgment should not be confused with the share of competence of the court that has made it).

Also, the section of the federal court in the state of Mato Grosso decided, in the first instance, in favor of inactive civil servants all over the country and granted preliminary injunctions in a matter about revenues to recognize the unenforceability of the social contribution taxes and to order the Federal Government not to carry out any debits from active, inactive or without registration renewal savings accounts (lawsuit number 96.003183-5 in the First Court, and lawsuit number 96.0003379-0/7100 in the Third Court, preliminary injunctions on June 21, 1996 and September 20, 1996, respectively. For the latter, the judge argued that the federal judge would have jurisdiction exercised all over the country, which is not close to our line of thinking).

For an issue concerning the financial system about the use of the INPC (National Consumer Price Index), instead of using the TR to adjust the debts, the federal court in Mato Grosso granted preliminary injunctions aiming at the suspension of the TR as an index of monetary 
adjustment of all the housing loan contracts and replaced it by the INPC, providing the borrowers with informative statements showing the amount of the debt: lawsuit number 96.2838-9 (First Court, preliminary injunction on September 4, 1996) and lawsuit number 96.00029741/7100 (Third Court, preliminary injunction on September 26, 1996). Many banks were sued together with the Federal Government. Both decisions mentioned the concurrent and optional jurisdiction of the Federal District.

Concerning the above matter, the 10th Chamber of the First Special Jurisdiction Appellate Court, in the State of São Paulo, made a similar decision for a collective action filed by IDEC in the state courts (Ac. number 581.942-1). Because of that judgment, Banco Mercantil de São Paulo lodged a complaint with the Supreme Court of Brasil. The reporting Justice Carlos Velloso suspended, by means of a preliminary injunction, the decision that had been made by the State Court of Appeals, using as reference the precedents in which the Supreme Court of Brasil had already granted preliminary injunctions with the same understanding. The injunctions had been granted by the First Court of the federal court in Minas Gerais (claims numbers 559, 564 and $557-\mathrm{MG}$ ) because, according to their understanding, the requirement of the fumus boni juris had been met, that is, the collective action, valid nationwide, and based on unconstitutional laws, becomes a declaration of unconstitutionality and encroaches on the jurisdiction of the Supreme Court (claim number 601-8/SP, in DJU May 7, 1996, page 14.584). In the merits, however, several claims were dismissed as the unconstitutionality had been argued incidenter tantum, although the decision was effective erga omnes [claim 597-SP (reporting Justice Néri da Silveira), claim 600-SP (the same reporting Justice), claim 602-SP (reporting Justice Ilmar Galvão), j. September 3, 1997, in "Informativo" number 82, Brasília, September 1 to 5, 1997)].

Then, it is possible to realize that the reporting Justice Ilmar Galvão's dissenting opinion, above transcribed, has clearly influenced on the jurisprudence of the other Appellate Courts.

\section{THE RES JUDICATA EFFECTIVE ALLOVER THE COUNTRY AFTER THE LAW NUMBER 9.424, OF SEPTEMBER 10, 1997}

The increasingly acceptance of the res judicata with effects all over the country, qualifying the decisions in the collective actions and projecting the effects of the preliminary injunctions, ended up confronting the interests of the Treasury Department, leading the executive branch to include in the Provisional Measure number 1.570 of March 26, 1997 (enacted as the Law 9.494 of September 10, 1997) the rule of the Article 3, which intended to keep the erga omnes effect 
within the territorial limits of the jurisdiction.

That is what will be analyzed, as follows.

The executive, followed by the legislative branch, was unfortunate twice.

In the first place, the executive branch erred on the side of intention. To restrict the scope of the res judicata in the collective actions means to multiply the number of litigations, which, on the one hand, confronts the philosophy of the collective suits, whose aim is to give a molecular treatment to solve the conflict of interests, instead of atomizing and pulverizing them; on the other hand, it causes the multiplication of lawsuits and the overload of the Courts of Appeals, demanding multiple jurisdictional answers when just one answer would be enough. At this moment, when the Brazilian legal system is seeking a way out even for binding precedents, the least we can say about the executive branch's effort to limit those effects is that it is on the wrong side of history.

Secondly, it erred on the side of incompetence. Unaware of the interaction between the Public Civil Action Act and the Consumer Protection Code and its various provisions, the executive branch considered that it would be enough to modify the Article 16 of the Law number $7.347 / 85$ to solve the problem. It was a clear mistake. In fact, the amendments made to the Article 16 of the Public Civil Action Act are ineffective.

Let us look at the evidence.

It has already been repeatedly mentioned the necessity to read the procedural rules in the Consumer Protection Code together with the rules in the Public Civil Action Act, according to what is established in the Article 90 of the former and the Article 21 of the latter.

This way, the article 16 of the Public Civil Action Act, in accordance with the meaning that was given to it by the Provisional Measure, cannot be interpreted without taking into consideration the Articles 93 and 103 of the Consumer Protection Code. that:

The Article 16, changed by the Provisional Measure, determines

"Article 16: A civil judgment shall constitute res judicata erga omnes within the territorial jurisdiction limits of the court that has rendered the judgment, except if the claim is dismissed due to insufficiency of evidence, in which case any other legitimate claimant may bring another action with the same ground, making use of new evidence." (The italicized words were added) 
However, the article has to be read together with the three items of the Article 103, which has not been amended.

A joint analysis of the above mentioned articles shows that the Article 16 of the Public Civil Action Act just regards the regime of the res judicata for the diffuse interests (at the most, collective), since the permissible prerogative of the non liquet caused by insufficient evidence is restricted to the items I and II of the Article 103, which refer to the above mentioned transindividual interests. As a matter of fact, the rule that governs the Article 16 of the Public Civil Action Act harmonizes perfectly only with the item I, Article 103, because of the expression erga omnes while the item II refers to the res judicata ultra partes. This way, in an overall view, the new rule is exclusively, all in all, in agreement with the hypothesis of the diffuse interests (Article 103, I) and, it has already shown the necessity of an analogical operation so that the Article 103, II (collective interests) may also be understood as modified. In this case the analogy may be applied, as there are no differences towards the regime of the res judicata between the diffuse and collective interests.

However, the regime of the res judicata for the homogeneous individual interests is totally different (Article 103, III) as the legislator used his own system, and this has been shown by a text that is completely distinct from the one of the provision: in one, because the res judicata erga omnes is effective only if the claim is sustained to benefit all the claimants and their descendents, and, in the other, because for this group of interests the legislator did not adopt the inexistence of the res judicata for a claim deemed groundless because of insufficient evidence.

Consequently, because of the amendment introduced to the Article 16 of the Public Civil Action Act, the Article 103, III of the Consumer Protection Code cannot be considered modified, not even by the analogical interpretation, since the situations established in both rules are far from being similar; in fact, they are totally distinct.

By the way, it could not be different. The Law number 7.347, of 1985, just governs the jurisdictional protection for the diffuse and collective interests, as one can infer from the Article 1 (item IV), and also due to the fact that the compensation for damages shall be deposited in a special fund account, created by that law, to be used to finance the restoration of the damaged property (indivisible) (Article 13). The creation of the category of the homogeneous individual interests is typical of the Consumer Protection Code and they are not governed by that law, except for the possibility of using the collective action for their protection, according to the schemes in the Consumer Protection Code (Public Civil Action Act, Article 21).

A first conclusion arises herein: the amendment of the Article 16 of the Law number 7.347/85 applies only to the res judicata in the 
actions aimed at protecting the diffuse and collective interests and the modifications can be considered just for the items I and II, Article 103 of the Consumer Protection Code. However, it is not relevant the regime of the res judicata in the collective actions aimed at protecting the homogeneous individual interests, governed exclusively by the item III of the Article 103 in the Consumer Protection Code, which remains unchanged.

And, paradoxically, the jurisprudence was having a strict position towards the effects of the res judicata erga omnes all over the national territory (see number 3 above) exactly in the field of the jurisdictional protection of the homogeneous individual interests, what provoked the reaction from the executive branch.

And there is more. The amendment to the Article 16 of the Public Civil Action Act, introduced by the Provisional Measure, is not only ineffective towards the res judicata in the actions to protect the homogeneous individual interests, and this issue has already been approached, but it is also inoperative towards the diffuse and collective interests. And, this time, the reason is the reference to the territorial jurisdiction.

The territorial jurisdiction for the collective actions is expressly regulated by the Article 93 of the Consumer Protection Code. The express rule of the lex specialis is for the jurisdiction of the state's capital city or the Federal District for the lawsuits in which the scope of the damage or the risk of damage is regional or national.

Therefore, to declare that the res judicata is limited "within the territorial jurisdiction limits of the court that has rendered the judgment" is nothing but the indication that it is necessary to search for the specification of the jurisdiction legal limits, that is, the parameters of the Article 93 of the Consumer Protection Code, which regulates the national and regional territorial jurisdiction for the collective actions.

We shall add the national and regional territorial jurisdiction, both in the field of the state-level courts as well as in the field of the federal courts.

All of what has been explained shall put an end to any doubt concerning the express provision about the territorial jurisdiction, with national or regional scope, in the collective actions to protect the homogeneous individual interests, which constitutes one more argument to show how inoperative the new Article 16 of the Public Civil Action Act is to the goals that the executive branch wanted to reach when the Article 3 of the Provisional Measure was enforced.

How about the diffuse and collective interests? We have already admitted that the amendment to the Article 16 of the Public Civil Action Act, introduced by the Provisional Measure, applies to the items I and II of the Article 103, and only to them. Now, it is a matter of finding out 
the range of the expression "within the territorial jurisdiction limits of the court that has rendered the judgment" for the diffuse and collective interests.

In the last analysis, it is necessary to verify if the territorial jurisdiction rule, whether national or regional, in the Article 93 of the Consumer Protection Code, is exclusive to the lawsuits for the protection of the homogeneous individual interests or if it is also intended to the jurisdictional protection of the diffuse and collective interests.

We have already said that our position is steady concerning the fact that, although inserted in the chapter about the "collective actions to protect the homogeneous individual interests", the Article 93 of the Consumer Protection Code governs every collective suit, comprising the actions to protect the diffuse and collective interests. Then, one cannot avoid using here the integrative method, aimed at fulfilling the gaps in the law, either by means of the extensive interpretation (extensive regarding the meaning of the rule) or by means of the analogy (extensive regarding the legislator's intention).

Ubi eadem ratio, ibi eadem juris dispositio. The necessary internal coherence of the legal system requires the elaboration of identical rules, which allow the verification of the identity of ground. If the Article 93 of the Consumer Protection Code were applicable only to the homogeneous individual interests, the result would be the rule of the territorial jurisdiction, with national or regional scope, just for the actions aimed at protecting those referred rights, while for the collective actions aiming at the protection of the diffuse and collective interests the national or regional jurisdiction would be vetoed. The result of this position is clearly absurd, causing it to be rejected by the reason and the common sense in order to preserve the legal system's coherence.

And there is more: the above mentioned provision tried (unsuccessfully) to restrict the jurisdiction, but a reference to the subject-matter can be found nowhere.

Now, the scope of the res judicata is determined by the pleading and not by the jurisdiction. The latter is a mere relation of adequacy between the proceedings and the judge and does not exercise any influence over the subject-matter. If the pleading has a wide range (with a national scope), it shall not be limited by the attempts to restrict the jurisdiction.

About the Article 16 in the Public Civil Action Act, we can conclude that:

- It does not apply to the res judicata in the collective actions whose aim is the protection for the homogeneous individual rights.

- It applies to the res judicata in the actions aimed at protecting 
the diffuse and collective interests; however, the amendment introduced to the article by the Provisional Measure is inoperative, since it is the special law itself that will extend the limits of the territorial jurisdiction in the collective actions, with national or regional scope.

- Anyway, what determines the scope of the res judicata is the pleading and not the jurisdiction. The latter is a mere relation of adequacy between the proceedings and the judge. If the pleading has a wide range (erga omnes), the judge will be competent to decide on the whole subject-matter.

- As a consequence, the new text of the provision is totally ineffective.

Those considerations, reproduced from a previous work ${ }^{1}$, are now being presented once again for deep and careful thought and to be considered by all those who are interested in the fortunes and the misfortunes of the collective actions.

\section{THE ATTACK AGAINST THE COLLECTIVE ACTION CONTINUES: THE PROVISIONAL MEASURE NUMBER 1.798- 1 OF FEBRUARY 11, 1999}

Once again the government makes use of the Provisional Measure as a tool to mine all the work developed along the years to attach importance to the associative moment, to facilitate the access to justice and to provide the judiciary branch with modern procedural tools, suitable for the protection of the supraindividual rights or interests. And now the means is the Provisional Measure number 1.798-1 of February 11,1999 , which adds some articles to the unfortunate law number 9.494/97, whose comments were made in the previous topic.

The Article 2, introduced to the above mentioned law, has the following text:

"Article 2-A: A civil decision, issued in a collective action filed by an associative entity to protect its members' interests and rights, shall comprise only those who were substituted, and are, by the time the action was filed, domiciled within the range of the territorial jurisdiction of the court that has rendered the judgment."

We can soon realize that the rule is only applicable to the

1 Ada Pellegrini Grinover, Brazilian Consumer Protection Code, with comments made by the authors of the Bill, several authors, Rio de Janeiro, Forense Universitária, 5th Edition, 1997, pp. $722 / 725$. 
collective and homogeneous individual interests, because in the field of the diffuse interests the holders of the standing are, by definition, undetermined and indeterminable, connected by factual circumstances, being impossible to know where they are domiciled. The Article 81, sole paragraph, I, of the Consumer Protection Code and which integrates the Law 7.347/85 is incompatible with the restriction and is immune to the incidence of the new rule.

But, even for the collective and homogeneous individual interests, the rule is ineffective. Once again, the executive branch was inept; all the above mentioned considerations about the change in the Article 16 of the Public Civil Action Act apply to the new provision. It is not a matter of the decision being ineffective, but the pleading. Also, "the range of the territorial jurisdiction of the court that has rendered the judgment" is defined in the Article 93, II, of the Consumer Protection Code, and the court where the decision was issued has national or regional jurisdiction, in accordance with the provisions in the Code.

The sole paragraph in the same Article 2-A, introduced to the Law number 9.494/97 has the following text:

\section{"Sole paragraph: In the collective actions filed against entities of the direct public administration, autarchies and foundations of the Union, States, Federal District and Municipalities, the minutes of the general meeting of the associative entity that has authorized the filing of the action must accompany the petition, together with a list of the associates' names and addresses."}

The restriction, which benefits the government alone, has effects concerning the Article 82, IV, of the Consumer Protection Code that, in the case of collective actions, conveys standing to "the associations legally operating for at least one year and whose institutional goals include the protection for the interests and rights comprised by this Code ${ }^{2}$ are exempt from presenting the general meeting authorization.' (The italicized words were added).

The requirement of the general meeting authorization together with the list of the associates' names and addresses, which represents an obstacle for the associations to access justice and is limited to the claims against the government and its autarchies and foundations, is a clear demonstration of the privilege that does not comply with the principle of the procedural equality that arises from the constitutional principle of isonomy. It is not a prerogative that could be explained

2 Once again, the application of the rules regarding all the collective actions shall be observed, in accordance with what is established in the Article 21 of the Public Civil Action Act. 
in view of the complex organization of the state or the para-state governmental agencies, allowing the unequal to be treated unequally. The government's defensive activity will not become easier because of that requirement, whose only goal is to prevent the associations from accessing justice in order to litigate.

Finally, the Article 2-B, introduced to the Law number 9.494/97 as well, refrains the satisfying provisional remedies (rectius, to accelerate the protection) in the cases of funds release, inclusion on the payroll, promotions, equalization of positions, salary raise or benefit improvements to the civil agents working for the Union, States, Federal District and Municipalities, including autarchies and foundations. The issue surpasses the scope of the collective actions, and shall be examined together with the other rules that restrict the general rule of the Article 273 of the Code of Civil Procedure. However, it is certain that for this matter, as well as for other topics (v.g. the motion for new trial), the constitutional principle of the isonomy, from which the procedural equality is a reflection, is heavily attacked.

\section{CONCLUSIONS}

Several years after the introduction of the jurisdictional protection for the diffuse and collective interests in Brasil, going through the evolutionary line that led to the recognition of the homogeneous individual rights, the balance would have been positive if the government had not attacked it in such an authoritarian way. After some arguments and certain advances and retreats that could even be predictable due to the natural difficulty to widely learn about the complexity of the new rules, we can say that the collective actions are a part of the current legal routine, despite the attacks. The remarkable quantity of demands and the adequate jurisdictional response enlightened the new procedural methods and showed the effort of the legitimate claimants (the first among them all is the Attorney General), the wide range of the actions brought to court and the recognition of the social body. We can assert that the collective actions have completely changed the Brazilian civil procedure, nowadays adherent to the social reality and the underlying policy, and to the controversies that constitute its subject-matter, leading it on the way of efficacy and effectiveness. Also, by means of the collective actions, the society has been able to exercise its citizenship rights in a more articulated way.

The judiciary branch is significantly inserted in this context, aware of its new role and its renewed importance, and by means of its judgments was able to occupy a leading position that promisingly points towards the future challenges.

The only dissonant note in this context is the government's 
attitude towards the use of Provisional Measures to reverse the situation, attacking the collective actions and trying to diminish its efficacy, to limit the access to justice, to frustrate the associative moment and to cause the judiciary branch to seem less important. The legislative branch, complacent or inattentive, has not been able to resist to the attacks and react to the government's attitudes. The resource may come from the courts. The lawyers and the Attorney General should look for them as a resort, providing the courts with the adequate interpretation of the new rules, so that the jurisdictional response may reflect the main directions for the collective actions as well as the general principles that govern them, which need to be evolutionary.

\section{REFERENCES}

BRASIL.Lei no 5.869, de 11 de Janeiro de 1973. Public Civil Action Act (Código de Processo Civil)

BRASIL. Lei $\mathrm{n}^{\circ} 7.347$, de 24 de julho de 1985

BRASIL. Lei $n^{\circ}$ 8.078, de 11 de setembro de 1990. Consumer Protection Code (Código de Defesa do Consumidor)

BRASIL. Lei $\mathrm{n}^{\circ}$ 9.494, de 10 de dezembro de 1997.(ela cita posteriormente uma lei 9424 do mesmo dia e ano) temos que corrigir isso. chequei é a certa é 9494

BRASIL. Medida provisória $\mathrm{n}^{\mathrm{o}}$ 1.570, de 26 de março de 1997

BRASIL. Medida provisória $n^{\circ}$ 1.798-1, de 11 de fevereiro de 1999

GRINOVER, Ada Pellegrini et al. Brazilian Consumer Protection Code: with comments made by the authors of the Bill. Rio de Janeiro: Forense Universitária, $5^{\text {a }}$ ed., 1997. pp. 722/725. 